\title{
KEGAGALAN DALAM BERDAKWAH \\ (Kajian Teoritis Dalam Buku Penyebab Gagalnya Dakwah Karya Dr. Sayyid M. Nuh)
}

\author{
Eka Wigianti \\ Fakultas Dakwah dan Komunikasi UIN Walisongo Semarang \\ Jl. Prof. Hamka Ngaliyan Semarang \\ ekawigi04@gmail.com
}

\begin{abstract}
This study aims to find out the causes of the failure of preaching described in the book "Penyebab Gagalnya Dakwah" by Dr. Sayyid M. Nuh. The book contains da'wah failures caused by the characteristics and actions taken by the dai. Some characteristics and behavior of dai that can cause failure of da' wah are futur, israaf, uzlah atau tafarrud, ittibaa'ul-hawa, 'adamut-Tatsabbut aw at-tabayyun, faudhal waqti, dan al-mira wa-jadal. Without realizing it by Dai, these traits can cause the failure of da'wah. The researcher used the content analysis method or content analyst to analyze the contents of the data with a qualitative approach. The results of this study are to find out what factors can cause failure to preach, especially those presented in the book 'Penyebab Gagalnya Dakwah'.
\end{abstract}

Keyword : failed, da'wah, book

\begin{abstract}
Abstrak
Penelitian ini bertujuan mengetahui penyebab kegagalan berdakwah yang dijelaskan dalam buku 'Penyebab Gagalnya Dakwah' karya Dr. Sayyid M. Nuh. Buku tersebut berisi tentang kegagalan dakwah yang disebabkan oleh sifat-sifat dan tindakan yang dilakukan oleh dai. Beberapa sifat dan perilaku dai yang dapat menyebabkan kegagalan dakwah adalah futur, israaf, uzlah atau tafarrud, ittibaa'ul-hawa, 'adamut-Tatsabbut aw at-tabayyun, faudhal waqti, dan al-mira wa-jadal. Tanpa disadari oleh dai, sifat-sifat tersebut dapat menyebabkan gagalnya dakwah. Peneliti menggunakan metode analisis isi atau content analisys yang menganalisa isi data dengan pendekatan kualitatif. Hasil dari penelitian ini adalah mengetahui faktor apa saja yang dapat menyebabkan kegagalan berdakwah, khususnya yang disampaikan dalam buku 'Penyebab Gagalnya Dakwah'.
\end{abstract}

Kata kunci : Kegagalan, Dakwah, Buku 


\section{A. PENDAHULUAN}

Dakwah yang dipahami sebagai tugas umat, menyampaikan kebenaran dan memerangi kemunkaran sejatinya menjadi tugas bagi setiap manusia. Sehingga semua manusia sebenarnya memiliki porsi yang sama dalam hal menyampaikan dakwah. Tentu hal ini diimbangi dengan keilmuan dan pemahaman yang memadai. Dewasa ini dakwah telah menjadi aktivitas yang banyak dilakukan di masyarakat. Banyak dai telah tersebar dari kota hingga ke pelosok desa. Bahkan suatu peringatan atau perayaan hari yang dianggap penting dirasa tidak lengkap jika tidak mengundang dai untuk memberikan tausiah. Hal ini terlihat dari mulai acara syukuran hingga acara adat besar seperti sedekah bumi atau laut juga turut menghadirkan dai (kiai) untuk menyampaikan materi dakwah.

Berbagai kajian rutin juga muncul dikalangan masyarakat. Mulai dari remaja hingga orang tua menjadikan pengajian atau kajian sebagai kebutuhan. Aktivitas berdakwah kemudian menjadi hal yang erat dengan masyarakat. Bahkan aktivitas dakwah bisa terjadi setiap waktu. Namun apakah aktivitas dakwah tersebut telah berhasil? Jika sudah berhasil, indikator apa sajakah yang menjelaskan bahwa dakwah telah berhasil? Jika belum, apakah penyebabnya? Mengapa meskipun telah dilakukan berulang kali dakwah masih belum berhasil dan perlu disempurnakan?

Dakwah memang menjadi tugas sepanjang masa di mana selama masih ada manusia, maka aktivitas dakwah masih terus dibutuhkan. Beberapa faktor yang menyebabkan kegagalan dalam dakwah bisa disebabkan oleh banyak pelaku dakwah. Bisa jadi kegagalan bersumber pada strategi dakwah, metode dakwah, pendekatan dakwah, mad'u yang tidak bisa menerima pesan dakwah, atau bahkan justru datang dari dalam diri dai.

Dewasa ini kegagalan dalam berdakwah biasanya dituduhkan pada strategi, maupun keragaman mad'u. Selain strategi yang salah diterapkan oleh dai ternyata juga terdapat penyebab lain yang dapat menyebabkan kegagalan dalam dakwah. Penyebab tersebut justru datang dari dai sebagai komunikator dalam dakwah. Tentu ini menjadi penting untuk diperhatikan dai dalam mengemban tugas dalam jalan dakwah.

Faktor yang berasal dari dalam diri dai tersebut banyak yang tidak disadari menjadi penyebab gagalnya dakwah. Sehingga penyebab internal dari diri dai seringkali diabaikan. Dai merasa bahwa pesan dakwah yang selama ini dilakukan sudah tepat dan akan mampu mengubah umat. Tidak ada perasaan mempertanyakan sifat dan sikap diri sendiri yang mungkin saja dapat menjadi penyebab gagalnya dakwah.

Tentu perjalanan menegakkan agama Islam menjadi tugas yang tidak mudah. Banyak hambatan dan tantangan yang harus dilalui oleh dai dalam menyampaikan materi dakwah pada mitra dakwahnya. Atas dasar inilah kemudian kajian mengenai penyebab gagalnya dakwah menjadi menarik untuk didiskusikan. Apalagi jika penyebab kegagalannya berasal dari dalam diri dai. Hal ini juga yang menjadikan buku 'Penyebab Gagalnya Dakwah' menjadi menarik untuk ditelaah lebih dalam. Sebab dalam buku ini menjelaskan hal yang 
jarang dibahas oleh penulis lainnya, yakni kegagalan dakwah yang disebabkan dari dalam diri dari.

\section{B. METODE PENELITIAN}

Penelitian ini merupakan penelitian teks media, yakni membahas tentang isi media dengan menggunakan pendekatan kualitatif. Penelitian ini menjadikan buku 'Penyebab Gagalnya Dakwah' sebagai rujukan data. Buku tersebut ditulis oleh Dr. Sayyid M. Nuh. Penelitian kualitatif memberikan hasil penelitian dalam bentuk data deskriptif, berupa kata-kata, tulisan, maupun perilaku dari orang yang diamati. (Tanzeh, 2009:100).

Jenis penelitian ini merupakan kajian library research atau penelitian kepustakaan. M. Nazir menyebutkan bahwa library research adalah jenis penelitian yang diadakan untuk menelaah buku-buku, literature, catatan, dan laporan pemecahan masalah (Nazir, 2010:91). Sebagai bentuk dari penelitian kepustakaan, maka dalam hal ini sumber data yang penulis gunakan adalah buku yang berkaitan dengan masalah penelitian. Sumber data primer berasal dari buku 'Penyebab Gagalnya Dakwah'. Sedangkan sumber data sekunder berasal dari buku lain yang berkaitan dengan masalah penelitian, yakni dakwah.

Teknik pengumpulan data yang digunakan adalah metode dokumentasi. Teknik pengumpulan data merupakan langkah strategis dalam penelitian. Hal ini disebabkan karena tujuan dari teknik pengumpulan data adalah untuk mendapatkan data (Sugiyono, 2011: 240). Dalam penelitian ini metode dokumentasi digunakan untuk mengumpulkan data primer. Menurut Arikunto metode dokumentasi merupakan suatu cara mencari data yang berkaitan dengan hal-hal yang berupa catatan, transkip, buku, surat kabar, majalah, prasasti, notulen, rapat, legger, agenda, dan sebagainya (Arikunto, 1996:134). Dalam penelitian kualitatif teknik analisis data bertujuan untuk menjawab rumusan masalah. Teknik analisis data dipahami sebagai cara untuk mencari data kemudian menata secara sistematis catatan hasil dari pengumpulan data tersebut. kemudian dilanjutkan dengan pemahaman terhadap objek penelitian. Analisis yang digunakan dalam penelitian ini adalah analisis isi. Analisis isi merupakan analisis yang mendalam dan detail untuk memahami produk isi dari media. Tidak hanya itu, pemahaman tersebut kemudian mampu untuk menghubungkan dengan realitas sosial yang ada (Kriyantono, 2010:249).

Berikut merupakan langkah yang peneliti lakukan sebelum mengalisa isi penyebab gagalnya dakwah adalah:

1. Membaca dan mencermati beragam buku dakwah, khususnya buku 'Penyebab Gagalnya Dakwah'.

2. Menganalisa isi penyebab kegagalan dakwah dalam buku 'Penyebab Gagalnya Dakwah'.

3. Mengidentifikasi isi buku tersebut kemudian menyimpulkan faktor interal dai yang dapat menyebabkan kegagalan berdakwah yang disampaikan oleh Dr. Sayyid M. Nuh. 


\section{B. HASIL DAN PEMBAHASAN}

\section{Biografi Dr. Sayyid M. Nuh}

Dr. Sayyid Muhammad Nuh merupakan alumnus Universitas Al-Azhar yang dikenal memiliki banyak buku dan karya di bidang pendidikan. Diantara banyak karyanya ialah Taujihaat Nabawiyyah, Aafaat alath Thariq, Syafaa Ash Shudur fii Tarikhis Sunnah wa Manahijil Muhadditsin, Ash Shahabah wa Juhuduhum fii Khidmatil Hadits, Attabi'un wa Juhuduhum fii Khidmatil Hadits, Manhajur Rasul fii Gharsi ruhil Jihad fii Nufusi Ash Habihi, Syakhshiyyatul Muslim bainal Fardiyyah wal Jama'iyyah, Ad-Da'wah Al-fardiyyah fii Dhai' il Manhaj Al-Islam, dll (www.eramuslim.com).

Profesi yang pernah diemban oleh Dr. Sayyid M. Nuh adalah Dosen Bidang Hadits di Universitas Al-Azhar Cairo Mesir, Dosen Tamu di Universitas Qatar Bidang Syari'ah, Tahun 19811982, Dosen Tamu di Fakultas Syari'ah Universitas Islam Kuwait, Tahun 1993-1999, dan Dosen Tamu di Fakultas Adab Universitas Uni Emirat Arab, Tahun 1982-1991. Dr. Sayyid M. Nuh meninggal setelah menderita penyakit jantung yang bertepatan dengan 30 Juli 2007. Sebelumnya beliau dirawat di rumah sakit "Daarul Fu'ad" di Kuwait, untuk menjalani proses pengobatan ke Cina (www.dakwatuna. com).

\section{Analisis Penyebab Kegagalan Dakwah} dalam buku 'Penyebab Gagalnya

\section{Dakwah'}

Sayyid M. Nuh dalam buku Penyebab Gagalnya Dakwah secara spesifik menyebutkan banyak beberapa hal dapat menyebabkan kegagalan dalam berdakwah. Buku tersebut menyebutkan secara spesifik beberapa hal dalam diri dai yang dapat menjadi penyebab kegagalan dalam berdakwah. Berikut di bawah ini beberapa hal yang dapat menjadi penyebab kegagalan dalam dakwah:

\section{Futuur}

Dimaknai sebagai terputus setelah terus menerus, diam setelah bergerak, sikap malas, lamban, dan santai setelah sebelumnya giat dan bersungguh-sungguh. Secara istilah futuur dipahami sebagai penyakit rohani (hati) yang efeknya minimal adalah timbul rasa malas, santai, lamban dalam melakukan suatu amaliyah yang sebelumnya dilakukan dengan penuh semangat dan menggebu-gebu. Biasanya penyakit futuur ini muncul ketika dakwah yang dilakukan telah cukup lama atau ketika dakwah mengalami sebuah hambatan. Beberapa faktor yang menyebabkan munculnya futuur adalah sikap ekstrem atau berlebihan dalam menjalankan aturan agama; melampaui batas kewajaran dalam melakukan hal yang mubah; memisahkan diri dari berjamaah dan lebih mengutamakan hidup menyendiri; tidak terprogramnya aktivitas dakwah yang akan dan ingin dilakukan.

Dai sebaiknya dapat melaksanakan aktivitas dakwah dan aktivitas amaliyah harian lainnya dengan konsisten. Perlu adanya usaha untuk menjaga semangat agar dakwah yang dilakukan dapat berhasil. Jika dai memiliki semangat yang tetap terjaga, maka berdakwah menjadi aktivitas yang menyenangkan dan bisa terlaksana dengan optimal (M. Nuh, 2000: 52). Tidak jarang kondisi mad'u atau mitra dakwah yang bervariatif menyebabkan dai mengalami 
penyakit futuur maupun masalah dakwah lainnya. Sebab ditinjau dari sisi psikologis masing-masing masyarakat memiliki karakteristik yang berbeda, sesuai dengan kondisi dan kontekstualitas lingkungannya. Jika dai tidak mengetahui siapa mad'u yang dihadapi, maka bisa jadi dakwah menjadi aktivitas yang mengalami kejenuhan (Bahri An-Nabiry, 2008: 230)

\section{Israaf}

Menurut bahasa israaf dimaknai sebagai melakukan sesuatu tetapi tidak dalam rangka kebaikan, melampaui batas. Sedangkan menurut istilah israaf berarti berlebihan dalam melakukan dan memilih sesuatu. Beberapa faktor penyebab munculnya penyakit hati israaf adalah keluasan rezeki setelah sebelumnya mengalami kesulitan materi; lalai terhadap bekal perjalanan dakwah yang harus diemban; lalai terhadap realitas yang tengah dihadapi oleh umat. Israaf dapat menyebabkan kegagalan dalam berdakwah karena dai menjadi lalai dengan banyak hal mengenai dakwah. Tak jarang aktivitas dakwah justru menjadi rutinitas yang berjalan berbarengan dengan sikap israaf. Salah satu hal yang dapat dilakukan untuk menghindari sifat israaf adalah dengan mengendalikan gejolak nafsu duniawi. Sehingga tidak semua keinginan duniawi harus dipenuhi, meskipun seorang dai bisa saja memenuhi keinginannya tersebut.

Menjadikan Rasulullah SAW sebagai suri tauladan juga dapat dijadikan kiat agar dai tidak terjerumus dalam sikap israaf. Selain itu dai juga perlu mengingat bahwa sejatinya jalan dakwah itu berat, penuh dengankelelahan, penolakan, dan kesakitan. Sehingga jalan tersebut tidak dapat dilalui dengan sikap boros, berlebihan, santai, dan bermewah-mewahan (M. Nuh, 2000: 60). Tentu sebagai seorang dai yang dipandang sebagai pengemban tugas suci memberikan pengaruh tersendiri. Sehingga berbuat baik menjadi sebuah keharusan. Menyadari akan fungsinya yang berat tersebut, maka penting bagi dai untuk membentengi diri dari sikap israaf. Sehingga meskipun segala kebutuhan hidup telah dapat terpenuhi, dai tidak berlebihan dalam kehidupannya. Karena tahapan pertama berdakwah adalah dakwah pada diri sendiri, sehingga jika dai yang sudah melakukan dakwah di banyak tempat harusnya juga telah mawas diri pada hal-hal yang dapat mengganggu aktivitas dakwahnya. Salah satunya adalah sifat israaf. Jika dai tidak mampu membentengi dan memberikan dakwah pada dirinya sendiri bagaimana ia akan berdakwah pada orang lain? Tentu ini dapat menyebabkan kegagalan dalam berdakwah sebab dai kehilangan kepercayaan dan simpati dari mitra dakwahnya (Bahri An-Nabiry, 2008: 138).

\section{3. 'Uzlah atau Tafarrud}

Secara bahasa, 'uzlah atau tafarrud berarti penjauhan atau pengasingan diri, menjauhkan sesuatu. Sedangkan secara istilah 'uzlah dipahami sebagai tindakan seseorang yang memilih hidup menyendiri daripada hidup bersama dengan orang lain. Secara luas sikap 'uzlah ini dipahami sebagai seorang dai yang memilih melakukan aktivitas dakwah sebagai rutinitas namun setelah menyampaikan materi dakwah, ia tidak peduli dengan kelanjutan mitra dakwahnya. Baginya dakwah selesai ketika materi telah disampaikan. Dai dengan sikap 'uzlah tidak mementingkan sikap tolong 


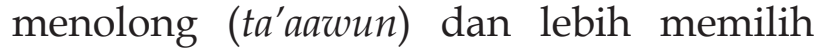
dakwah fardiyah atau dakwah individual.

Beberapa faktor yang dapat menjerumuskan dai kepada sikap 'uzlah adalah salah memahami anjuran 'uzlah; memaknai 'uzlah para ulama sebagai rujukan tekstual tanpa melihat konteks; lalai terhadap tanggung jawab dakwah dan bermasyarakat; menjadikan ujian dalam berdakwah sebagai alasan untuk bersikap 'uzlah. Salah satu dampak dari sikap 'uzlah ini adalah menjadikan dai apatis pada permasalahan yang sedang dihadapi umat. Sehingga hubungan antara dai dengan mitra dakwah menjadi hubungan yang tidak selaras. Dai hanya menyampaikan materi dakwah kemudian melepaskan diri dari masyarakat sebagai mitra dakwah, sedangkan mitra dakwah tetap melakukan hal-hal yang menyimpang dari agama dan tidak peduli dengan materi dakwah yang telah disampaikan oleh dai. Karena bisa jadi apa yang disampaikan dai justru tidak sesuai dengan permasalahan yang sedang dihadapi oleh mitra dakwah. Sehingga sikap 'uzlah yang salah pemaknaan perlu dihindari. Agar dai dapat memberikan solusi bagi permasalahan di masyarakat. Dengan berbaur dan hidup bermasyarakat dai dapat mengetahui permasalahan apa saja yang tengah terjadi dan solusi apa yang dapat dai berikan. Tentu perlu ada bentengan diri sehingga dai tidak terjerumus dalam masalah di masyarakat.

\section{Ittibaa'ul-hawa}

Dalam Bahasa Arab kata al-hawa mengandung beberapa arti, yakni kecenderungan pada hal yang disukai; keinginan jiwa pada hal-hal yang disenangi; rasa cinta seseorang terhadap sesuatu yang menguasai hatinya; kecintaan terhadap sesuatu sehingga sangat mendalam dan menguasai perasaan. Dari penjelasan tersebut memberikan pengertian menurut bahasa yakni mengikuti kata hati atau menuruti kehendak yang sangat mendalam dalam jiwa. Sedangkan menurut istilah pengertian ittibaa'ul-hawa adalah sikap mengekor pada hal yang disukai oleh hati; kecenderungan mengikuti penilaian hati tanpa mempertimbangkan logika atau rujukan lain sesuai syariat dan mempertimbangkan akibatnya.

Beberapa hal yang dapat menyebabkan sikap ittibaa'ul-hawa adalah lemah dalam mengenal Allah dan urusan akhirat; kecintaan pada dunia dan lalai pada urusan akhirat; dakwah hanya sebagai rutinitas sekedar menyampaikan materi dakwah; sempit dalam melihat perbedaan urusan agama. Dampak dari sikap ittibaa'ul-hawa ini salah satunya adalah menganggap bahwa dirinya lebih baik dari pada golongan lainnya sehingga menyalahkan dan menimbulkan pertikaian dalam dakwah. Akibat buruknya adalah perpecahan dalam beragama (M. Nuh, 2000: 210).

DalamperjalanandakwahdiIndonesia, persoalan perbedaan pemahaman tidak lagi menyangkut hal-hal kecil, namun juga pada aspek besar lainnya. Diantara aspek yang turut berhubungan dengan perbedaan pemahaman adalah aspek politik, sosialbudaya, dan pendidikan. Sehingga dengan adanya perbedaan-perbedaan tersebut, misi dakwah seharusnya dapat diarahkan pada kepentingan yang lebih luas, bukan hanya soal kepentingan dai. Kepentingan yang lebih luas misalnya pemberdayaan ekonomi umat, pendidikan politik, peningkatan 
kualitas pendidikan Islam, dan lainnya yang masih dapat terus diupayakan demi kemajuan umat Islam (Basit, 2006: 188).

\section{5. 'Adamut-Tatsabbut Aw At-Tabayyun}

Kata at-tatsabbut dalam Bahasa Arab memiliki beberapa pengertian, diantaranya mencari informasi yang dapat meneguhkan pada suatu masalah; mencari hakikat dalam suatu masalah. Sedangkan at-tabayyun diartikan sebagai mencari sesuatu yang dapat memperjelas; merenungi dengan perlahan, tidak tergesa-gesa dalam suatu yang belum jelas. Sehingga pengertian 'adamu at-tatsabbut aw at-tabayyun ialah sikap tergesa-gesa dalam menilai sesuatu tanpa didahului dengan upaya mencari kebenaran informasi tersebut. Sedangkan pengertian dalam istilah Islam dan dakwah adalah sikap terburu-buru, tidak seksama, tidak teliti dalam memberikan penilaian terhadap hal-hal yang terjadi pada kaum muslimin. Sehingga jika dai berdakwah dengan pemahaman yang dangkal, permasalahan umat tidak terselesaikan atau justru menimbulkan masalah baru di masyarakat.

Faktor-faktor yang dapat menyebabkan sikap 'adamu at-tatsabbut aw at-tabayyun adalah tertipu dengan perkataan buruk; tidak mengerti metode ketelitian dalam menganalisa suatu masalah di masyarakat. Beberapa fenomena 'adamu at-tatsabbut aw at-tabayyun yang terjadi di masyarakat adalah bermusuhan dengan non muslim atau justru dengan sesama aktivis dakwah; tidak bersedia menerima perbedaan atau tidak mendengarkan argumentasi dari kelompok lain; melihat apa yang ia ketahui sebagai kebenaran dan sesuatu lain yang bertentangan sebagai sesuatu yang salah. Sedangkan dampak buruk dari sikap 'adamu at-tatsabbut aw attabayyun ini adalah munculnya kebencian; rusaknya barisan umat muslim yang telah terbentuk; hilangnya rasa simpati dari umat (M. Nuh 2000: 286).

\section{Faudhal Waqti}

Secara bahasa al-faudha memiliki arti percampuran aneka perkara, satu sama lain. Menurut istilah faudhal waqti diartikan sebagai mencampurkan berbagai perkara dan memandangnya berada pada satu tingkat kepentingan dan keuntungan. Di samping tiadanya kesesuaian antara berbagai kewajiban dan pemanfaatan waktu. Dalam pandangan Islam faudhal waqti dapat berwujud dalam bentuk menyia-nyiakan waktu luang tanpa kesibukan yang bermanfaat, menyibukkan diri dengan hal sekunder atau perbuatan yang tidak menyentuh unsur kemanfaatan, menumpuk pekerjaan yang banyak dalam satu waktu (Machasin, 2015: 76).

Fenomena faudhal waqti dalam urusan dakwah adalah dai menyampaikan materi dakwah tanpa melihat keadaan sosial mitra dakwah yang dihadapi. Sehingga berbagai masalah dicampur adukkan dan waktu yang digunakan pun menjadi kurang bermanfaat atau bahkan sia-sia. Dalam hal ini dai perlu memiliki ketrampilan dalam mengatur waktu penyampaian materi dengan kesesuaian keadaan mitra dakwah. Sebab tidak jarang materi dakwah telah sesuai, namun karena pengaturan penyampaian waktu yang tidak tepat menyebabkan kegagalan dalam dakwah (M. Nuh, 2000: 186).

Realitas tersebut kemudian memunculkan istilah 'budaya kaset' di 
mana tausiah atau ceramah yang dilakukan oleh dai kemudian hanya bersifat komersil. Tentu kemudian dai perlu memiliki manajemen yang tepat dalam mengemban tugasnya. Salah satu yang menjadi penting untuk diperhatikan oleh dai agar dakwahnya tidak gagal adalah media yang digunakan untuk berdakwah. Perlu adanya kesesuaian antara dai dengan media yang banyak diakses oleh mitra dakwah. Dengan demikian diharapkan faudhal waqti tidak menjadi penyebab kegagalan dalam dakwah dan dapat diatasi dengan tepat (Basit, 2006: 51).

\section{Al-mira wa-jadal}

Dalam Bahasa Arab al-mira dimaknai sebagai pertengkaran sedangkan al-jadal didefinisikan sebagai perdebatan. Dalam istilah dakwah al-mira diartikan sebagai setiap sanggahan terhadap pembicaraan orang lain dengan cara menampakkan kecacatan, baik dari ucapan, pesan yang disampaikan, cara penyampaian, maupun subjek yang menyampaikan. Sementara aljadal atau perdebatan didefinisikan sebagai tindakan yang bertujuan untuk membuat orang lain tidak berkutik, melemahkan, dan menyatakan kekurangannya, dengan cara mencela. Pada umumnya, al-jadal digunakan dalam istilah ilmiah, sedangkan al-mira bersifat umum, mencakup masalah ilmiah maupun non ilmiah. Belakangan ini masalah yang sering muncul dalam masalah dakwah adalah pertengkaran dan perdebatan antar aktivis dakwah (M. Nuh, 2000: 216).

Beberapa faktor yang dapat menyebabkan munculnya pertengkaran dan perdebatan antar aktivis dakwah adalah tidak memperhatikan etika pemberian nasihat; kecenderungan menganggap bahwa dakwah adalah soal menang dan kalah; menyibukkan diri dengan ilmu berdebat dan berdiskusi sebelum membentengi diri dengan kitab dan sunnah. Tentu hal ini bukan berarti diskusi yang memicu perdebatan harus dihindari, namun cara penyampaian isi diskusi yang harus diperhatikan (M. Nuh, 2000: 220). Jika ingin meneladani strategi dakwah yang dilakukan oleh Rasulullah SAW di Madinah, maka pertengkaran dan perdebatan dapat dihindari. Sebab dakwah yang dilakukan oleh Rasulullah SAW saat itu adalah dakwah lintas budaya.

$$
\text { Upaya-upaya yang dilakukan }
$$
Rasulullah SAW ketika berdakwah di Madinah adalah dengan mencari persamaan bukan perbedaan, baik sesama muslim maupun non muslim. Rasulullah SAW juga berusaha menciptakan suasana dakwah yang menimbulkan sikap persaudaraan diantara manusia, meskipun berbeda agama. Dengan kata lain, strategi pendekatan dakwah yang dilakukan Rasulullah dapat berhasil karena Rasulullah SAW menerapkan pendekatan dengan penuh persahabatan dan toleransi tinggi (Anas, 2015: 57).

\section{SIMPULAN}

Berdasarkan uraian di atas peneliti dapat menyimpulkan bahwa dalam buku 'Penyebab Gagalnya Dakwah' yang ditulis oleh Dr. Sayyid M. Nuh ini memiliki dua jilid dengan dua puluh delapan sub bab. Setiap sub bab menjelaskan dengan terperinci halhal yang dapat menyebabkan kegagalan dalam dakwah. Buku ini secara spesifik mengambil angel kegagalan dari dai sebagai penyampai materi dakwah. Sedangkan 
dalam makalah ini penulis mengambil tujuh hal yang dapat menyebabkan kegagalan dakwah. Ketujuh hal tersebut penulis ambil menyesuaikan dengan keadaan dan perkembangan dakwah di masa sekarang.

Diantara hal yang dapat menyebabkan kegagalandakwahadalahsikapfutuur, israaf, 'uzlah, ittibaa'ul-hawa, 'adamut-tatsabbut aw at-tabayyun, faudhal waqti, al-mira wa-jadal. Futuur artinya lamban, malas, atau santai dalam berdakwah setelah sebelumnya menggebu-gebu dalam menyampaikan materi dakwah. Tentu sebagai manusia biasa dai bisa saja mengalami hal tersebut apalagi jika mad'u yang dihadapi bermacam-macam. Israaf artinya berlebihan dalam pemenuhan kebutuhan seorang dai. Biasanya keadaan ini diawali dengan keadaan dai yang berangkat dari ekonomi menengah atau bawah kemudian setelah menjadi dai menjadi ekonomi atas. Tidak jarang kemudian perilaku israaf justru membuat dai mengalami kegagalan dalam dakwahnya.

'Uzlah dimaknai luas sebagai sikap memilih menyendiri dan tidak memperhatikan permasalahan mitra dakwah. Sehingga dakwah menjadi rutinitas biasa yang entah memberikan perubahan atau tidak, dai tidak peduli. Dalam hal ini dai merasa dirinya terlepas dari persoalan mitra dakwah. Ittibaa'ul-hawa dalam urusan dakwah yang sering dialami oleh dai adalah pada hal senang mengekor pada hal yang ia sukai secara hati tanpa mempertimbangkan logika dan konteks lainnya. Tentu hal seperti ini menjadi bahaya dalam penyampaian dakwah jika dai mengalami persoalan ittibaa'ulhawa. 'Adamut-tatsabbut aw at-tabayyun diartikan sebagai sikap tergesa-gesa dalam menilai sesuatu tanpa mempertimbangkan banyak hal dan melakukan pengecekan kebenarannya.

Faudhal waqti dimaknai sebagai sikap membuang-buang waktu dengan tidak memberikan materi dakwah yang relevan. Sehingga dalam hal ini dikhawatirkan dai justru akan menyampaikan hal yang tidak sesuai dengan kebutuhan mitra dakwahnya. Al-mira wa-jadal bisa dikatakan sedang menjadi permasalahan dakwah yang dialami oleh dai di masa sekarang. Munculnya perdebatan dan pertengkaran yang tidak dapat diatasi antar aktivis dakwah justru menjadi masalah besar yang dapat menyebabkan kegagalan dalam berdakwah. Untuk menghindari kemudharatan dari al-mira wa-jadal dai dapat mengambil suri tauladan Rasulullah SAW yang lebih mengutamakan persamaan dari pada perbedaan. 
DAFTAR PUSTAKA

Anas, Ahmad. 2015. Dakwah Nabi Muhammad SAW Terhadap Masyarakat Madinah Melalui Pendekatan Komunikasi Antar Budaya. Fakultas Dakwah dan Komunikasi UIN Walisongo Semarang.

Arikunto, Suharsim. 1996. Prosedur Penelitian Suatu pendekatan Praktik. Jakarta: Rineka Cipta.

Bahri An-Nabiry, Fathul. 2008. Meniti Jalan Dakwah Bekal Perjuangan Para Dai. Jakarta: Amzah.

Basit, Abdul. 2006. Wacana Dakwah Kontemporer. Yogyakarta: Pustaka Pelajar dan STAIN Purwokerto Press.

Kriyantono, Rachmad. 2010. Teknik Praktis Riset Komunikasi, Jakarta: Kencana.

Machasin. 2015. Psikologi Dakwah Suatu Pengantar Studi. Semarang: Karya Abadi Jaya.

M. Nazir. 2003. Metode Penelitian. Jakarta: Ghalia Indonesia.

M. Nuh, Sayyid. 2000. Penyebab Gagalnya Dakwah Jilid 1. Jakarta: Gema Insani Press.

M. Nuh, Sayyid. 2000. Penyebab Gagalnya Dakwah Jilid 2. Jakarta: Gema Insani Press.

Sugiyono. 2011. Metode Penelitian Kuantitatif Kualitatif dan RED. Bandung: Alfabeta.

Tanzeh, Ahmad. 2009. Pengantar Metode Penelitian. Yogjakarta: Teras. https://www.eramuslim.com/ diakses pada Jumat, 24 Mei 2019 pukul 10.02 WIB.

https://www.dakwatuna.com/ diakses pada Jumat, 24 Mei 2019 pukul 09.54 WIB. 